\title{
The association between bone age advancement and insulin in prepubertal children with obesity
}

\author{
Hae Sang Lee*, Hwal Rim Jeong, Eunbyul Kwon, Jin Soon Hwang \\ From 8th APPES Biennial Scientific Meeting \\ Darwin, Australia. 29 October - 1 November 2014
}

\begin{abstract}
Aims
Obesity is associated with bone age (BA) advancement of unclear etiology. In animal study, insulin may directly modulate skeletal growth. Our objective was to investigate the association with BA maturation and insulin levels in children with overweight and obesity.
\end{abstract}

\section{Methods}

In this cross-sectional study of 103 prepubertal children, anthropometric data and hormonal values during oral glucose tolerance test were measured. Subjects were divided into two groups by the difference between BA and chronological age (CA) (noted as BA-CA).

\section{Results}

The study population included 49 (47.6\%) males and 54 $(52.4 \%)$ females with a mean age of $7.6 \pm 1.6$ years. The advanced bone age group defined as BA-CA $>1$ year $(n=53)$ had significantly higher HOMA-IR, fasting insulin levels and lower quantitative insulin sensitivity check index (QUICKI). Also, BA-CA was significantly correlated with fasting insulin $(\mathrm{r}=0.315, \mathrm{P}<0.001)$, HOMA-IR $(\mathrm{r}=0.288, \mathrm{P}<0.001)$, and QUICKI $(\mathrm{r}=-0.353, \mathrm{P}<0.001)$. In multiple regression analysis, fasting insulin was identified as significant independent predictors for BA-CA.

\section{Conclusion}

Skeletal age is more advanced in overweight and obese children with hyperinsulinemia and insulin resistance. These findings suggest that insulin may modulate skeletal growth.

Published: 28 April 2015

Department of Pediatrics, Ajou University School of Medicine, Ajou University Hospital, Suwon, Korea

C 2015 Lee et al; licensee BioMed Central Ltd. This is an Open Access article distributed under the terms of the Creative Commons Attribution License (http://creativecommons.org/licenses/by/4.0), which permits unrestricted use, distribution, and reproduction in any medium, provided the original work is properly cited. The Creative Commons Public Domain Dedication waiver (http:// creativecommons.org/publicdomain/zero/1.0//) applies to the data made available in this article, unless otherwise stated.
doi:10.1186/1687-9856-2015-S1-P71
Cite this article as: Lee et al:: The association between bone age advancement and insulin in prepubertal children with obesity. International Journal of Pediatric Endocrinology 2015 2015(Suppl 1):P71. and take full advantage of:

- Convenient online submission

- Thorough peer review

- No space constraints or color figure charges

- Immediate publication on acceptance

- Inclusion in PubMed, CAS, Scopus and Google Scholar

- Research which is freely available for redistribution 